\title{
First Attack of Status Epilepticus in Adults: Etiology and Risk Factors
}

\author{
AHMED I. EL-SHEIKH, M.Sc.; AZZA A. GHALI, M.D.; HASSAN G. NASSAR, M.D. and \\ WAEL A. FADEL, M.D. \\ The Department of Neuropsychiatry, Faculty of Medicine, Tanta University, Tanta, Egypt
}

\begin{abstract}
Background: Status Epilepticus (SE) is a common lifethreatening neurological emergency the etiology of SE varies according to age and prior history of seizures. In people known to be epileptic poor compliance and drug withdrawal are the commonest causes of SE. On the other hand in patients with no prior seizure history strokes, head traumas, CNS infections, cardiac arrests and metabolic disturbances are the most common causes.
\end{abstract}

Aim of Study: Is to study the possible etiologies and outcome of first attack of SE in adults.

Patients and Methods: This was a 6-month duration cross sectional study done at Neuropsychiatry Department, Tanta University Hospital, started from July 2016. All patients presented by first attack of SE over the age of 18 years and didn't have previous history of SE, were considered.

Results: Of 42 patients included in the study $35(83.3 \%)$ had non refractory SE while $7(16.7 \%)$ had RSE. 37 patients survived $(88.1 \%)$ and 5 patients died (11.9\%). Analysis of statistically significant and most clinically important variables showed that these factors were significantly higher in RSE, cryptogenic etiology $(p=0.024)$, EEG changes $(p=0.015)$. number of AEDs $(p=0.001)$, duration of hospitalization $(p=$ $0.037)$, complications due to hospitalization $(p=0.015)$, EMSE scores $(p=0.001)$.

Conclusion: Most patients presented by SE over the age of 18 has no prior history of epilepsy. CVAs are the leading cause of de novo SE in adults followed by metabolic derangements. Refractory Status Epilepticus (RSE) is associated with prolonged duration of hospitalization and higher rates of complications compared to non-refractory SE. Complications due to seizures were the most common followed by side effects of AEDs while complications of prolonged hospitalization were the least common. EEG monitoring is an important tool both in managing and predicting the outcome of status epilepticus. STESS and EMSE scoring systems are easy to use bed side tools to help in predicting the outcome of SE.

Key Words: Status - Epilepticus - Risk factors - Etiology.

Correspondence to: Dr. Ahmed I. El-Sheikh, The Department of Neuropsychiatry, Faculty of Medicine, Tanta University, Tanta, Egypt

\section{Introduction}

STATUS Epilepticus (SE) is a common lifethreatening neurological emergency, it is defined as a state of continuous seizure activity for more than 5 minutes or two or more discrete seizures between which there is incomplete recovery of consciousness [1]

The etiology of SE varies according to age and prior history of seizures. In people known to be epileptic poor compliance and drug withdrawal are the commonest causes of SE. On the other hand in patients with no prior seizure history strokes, head traumas, Central Nervous System (CNS) infections, cardiac arrests and metabolic disturbances are the most common causes [2].

Seizures lasting approximately 30 to 45 minutes can cause cerebral injury especially in limbic structures such as the hippocampus, this damage is mainly a consequence of glutamate mediated excitotoxicity and doesn't appear to be due to excessive metabolic demand imposed by repetitive neuronal firing [3]

The fundamental pathophysiology of SE involves a failure of mechanisms that normally abort an isolated seizure. This failure can arise from abnormally persistent excessive excitation or ineffective recruitment of inhibition [4] .

Status epilepticus is associated with high rates of mortality and morbidity that is why rapid initiation of treatment is required to control such fatal condition and ensure a better outcome for the patients. Complications of SE are either due to seizures itself, complications of Antiepileptic Drugs (AEDs) and complications of hospitalization, that's why determining the risk factors associated with refractoriness to treatment, morbidity and mortality is essential to properly manage patients with SE and improve their outcome [5] 


\section{Patients and Methods}

This study was conducted in the Neuropsychiatric Department of Tanta University Hospital on 42 patients with first attack of Status Epilepticus (SE) in the period between July 2016 and January 2017. They were classified into non refractory group (35 patients) and refractory group ( 7 patients).

Each patient was subjected to full history taking, thorough general and neurological examination brain CT and/or MRI. Routine laboratory investigations including complete blood count, liver functions, renal functions, arterial blood gases and serum electrolytes. Specific laboratory investigations in certain cases e.g: Cerebro spinal fluid analysis. Electroencephalogram (EEG) monitoring in the first 24hrs after hospitalization. Status Epilepticus Severity Score (STESS) and Epidemiology based Mortality Score in Status Epilepticus (EMSE) were calculated for each patient.

\section{Results}

There was that no statistically significant difference between both groups as regard gender and age distribution (Table 1).

Table (1): Demographic data of both groups.

\begin{tabular}{lllll}
\hline Characteristics & $\begin{array}{l}\text { Group A (n=35) } \\
\text { Non-refractory }\end{array}$ & $\begin{array}{c}\text { Group B (n=7) } \\
\text { Refractory }\end{array}$ & $\begin{array}{l}\text { Sig. } \\
\text { test }\end{array}$ & $p$ \\
\hline $\begin{array}{l}\text { Age (in years): } \\
\text { Mean } \pm \text { S.D }\end{array}$ & $47.8 \pm 10.4$ & $39.5 \pm 16.4$ & $t$ & 0.325 \\
$\quad$ Range & $20-85$ & $18-74$ & 1.050 & \\
Gender: & & & & \\
Male & $18(51.4 \%)$ & $2(28.6 \%)$ & $\chi^{2}$ & 0.269 \\
Female & $17(48.6 \%)$ & $5(71.4 \%)$ & 1.222 & \\
\hline
\end{tabular}

Acute symptomatic causes were the most common in both groups, remote symptomatic causes were more common in the non-refractory group while cryptogenic causes were more common in the refractory group. Cerebrovascular causes were the most common overall while metabolic causes were more common in the non-refractory group and unknown etiologies were more common in the refractory group with a statistically significant difference (Table 2).

The mean values of random blood glucose, blood pressure and body temperature on admission were higher in the refractory group but without any statistical significance (Table 3).

EEG abnormalities were significantly more encountered in patients with refractory status epilepticus, Lateralized Periodic Discharges (LPDs) were the most common EEG change in our study (Table 4).

Table (2): Possible etiologies among studied patients.

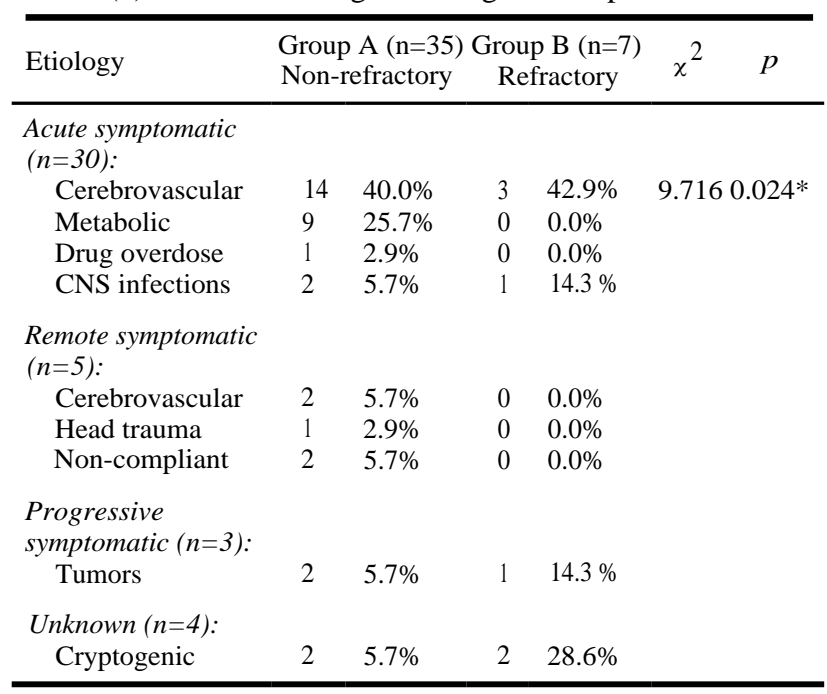

Table (3): Clinical characteristics of the studied groups.

\begin{tabular}{|c|c|c|c|c|c|c|}
\hline \multirow{2}{*}{$\begin{array}{l}\text { Characteristics } \\
\text { Blood pressure: }\end{array}$} & \multicolumn{5}{|c|}{ Group A $(n=35)$ Group B $(n=7)$ Sig. } & $p$ \\
\hline & & & & & & \\
\hline Normotensive & 19 & $54.3 \%$ & 19 & $154.3 \%$ & $x^{2}$ & 0.756 \\
\hline Hypotensive & 6 & $17.1 \%$ & 6 & $17.1 \%$ & 0.559 & \\
\hline Hypertensive & 10 & $28.6 \%$ & 10 & $28.6 \%$ & & \\
\hline \multicolumn{7}{|l|}{$\begin{array}{l}\text { Systolic blood } \\
\text { pressure: }\end{array}$} \\
\hline Mean \pm S.D & \multicolumn{2}{|c|}{$125.1 \pm 26.8$} & \multicolumn{2}{|c|}{$125.1 \pm 26.8$} & $t-0.947$ & 0.370 \\
\hline \multicolumn{7}{|l|}{$\begin{array}{l}\text { Diastolic blood } \\
\text { pressure: }\end{array}$} \\
\hline Mean \pm S.D & \multicolumn{2}{|c|}{$74.2 \pm 15.6$} & \multicolumn{2}{|c|}{$74.2 \pm 15.6$} & $t-0.432$ & 0.676 \\
\hline \multicolumn{7}{|l|}{ Temperature: } \\
\hline Normal temp. & 26 & $74.3 \%$ & 26 & $74.3 \%$ & & 0.738 \\
\hline Hypothermia & 2 & $5.7 \%$ & 2 & $5.7 \%$ & 0.606 & \\
\hline Hyperthermia & 7 & $20.0 \%$ & 7 & $20.0 \%$ & & \\
\hline Mean \pm S.D & \multicolumn{2}{|c|}{$37.3 \pm 0.6$} & \multicolumn{2}{|c|}{$37.3 \pm 0.6$} & $t-1.351$ & 0.210 \\
\hline \multicolumn{7}{|l|}{$\begin{array}{l}\text { Random blood } \\
\text { glucose: }\end{array}$} \\
\hline Normal & 29 & $82.9 \%$ & 29 & $82.9 \%$ & $x^{2}$ & 0.800 \\
\hline Hypoglycemia & 2 & $5.7 \%$ & 2 & $5.7 \%$ & 0.446 & \\
\hline Hyperglycemia & 4 & $11.4 \%$ & 4 & $11.4 \%$ & & \\
\hline Mean \pm S.D & \multicolumn{2}{|c|}{$201.3 \pm 102.1$} & \multicolumn{2}{|c|}{$201.3 \pm 102.1$} & $t-0.234$ & 0.819 \\
\hline
\end{tabular}

Table (4): EEG changes in the studied groups.

\begin{tabular}{lcccccc}
\hline \multirow{2}{*}{ EEG changes } & \multicolumn{2}{c}{$\begin{array}{l}\text { Group A (n=35) } \\
\text { Non-refractory }\end{array}$} & Refractory & $\chi^{2}$ & $p$ \\
\hline No changes & 12 & $34.3 \%$ & 0 & $0.0 \%$ & 12.300 & $0.015^{*}$ \\
Burst suppression & 1 & $2.9 \%$ & 3 & $42.9 \%$ & & \\
GPDs & 5 & $14.3 \%$ & 1 & $14.3 \%$ & & \\
LPDs & 10 & $28.6 \%$ & 2 & $28.6 \%$ & & \\
ASIDs & 7 & $20.0 \%$ & 1 & $14.3 \%$ & & \\
\hline GPDs : Generalized Periodic Discharges. & & & \\
LPDs : Lateralized Periodic Discharges. & & & \\
ASIDs : After Status Epilepticus Ictal Discharges.
\end{tabular}

The mean number of AEDs used was significantly higher in the refractory group (Table 5). 
Table (5): Number of antiepileptics used among the studied groups.

\begin{tabular}{lcccccc}
\hline $\begin{array}{l}\text { No. of } \\
\text { antiepileptics }\end{array}$ & $\begin{array}{c}\text { Group A (n=35) } \\
\text { Non-refractory }\end{array}$ & $\begin{array}{c}\text { Group B (n=7) } \\
\text { Refractory }\end{array}$ & $\begin{array}{c}\text { Sig. } \\
\text { test }\end{array}$ & $p$ \\
\hline No drugs & 2 & $5.7 \%$ & 0 & $0.0 \%$ & $\chi^{2}$ & $0.001^{*}$ \\
One drug & 6 & $17.1 \%$ & 0 & $0.0 \%$ & 42.000 & \\
Two drugs & 25 & $71.4 \%$ & 0 & $0.0 \%$ & & \\
Three drugs & 2 & $5.7 \%$ & 0 & $0.0 \%$ & & \\
Four drugs & 0 & $0.0 \%$ & 4 & $57.1 \%$ & & \\
Five drugs & 0 & $0.0 \%$ & 3 & $42.9 \%$ & & \\
Mean \pm S.D & $1.8 \pm 0.6$ & $4.43 \pm 0.5$ & $t-11.572$ & $0.001^{*}$ \\
\hline
\end{tabular}

There was statistically significant relationship between the type of SE and the duration of hospitalization as the mean duration was higher in patients with RSE (Table 6).

Table (6): Relationship between possible etiology and outcome.

\begin{tabular}{lcccc}
\hline $\begin{array}{l}\text { Hospitalization } \\
\text { duration }\end{array}$ & $\begin{array}{l}\text { Group A (n=35) } \\
\text { Non-refractory }\end{array}$ & $\begin{array}{c}\text { Group B }(\mathrm{n}=7) \\
\text { Refractory }\end{array}$ & $\begin{array}{c}\text { Sig. } \\
\text { test }\end{array}$ & $p$ \\
\hline Mean \pm S.D & $5.5 \pm 4.4$ & $10.7 \pm 5.2$ & $t-2.508$ & $0.037^{*}$ \\
\hline
\end{tabular}

The complications due to fits were the most common in both groups but significantly higher in Group A while the complications related to hospitalization were more common in Group B but without statistical significance. Also the survival rate was higher in Group A but with no statistical significance (Table 7).

Table (7): Outcome of both studied groups.

\begin{tabular}{|c|c|c|c|c|}
\hline Variables & $\begin{array}{l}\text { Group A } \\
(\mathrm{n}=35) \\
\text { Non- } \\
\text { refractory }\end{array}$ & $\begin{array}{c}\text { Group B } \\
(\mathrm{n}=7) \\
\text { Refractory }\end{array}$ & $x^{2}$ & $p$ \\
\hline $\begin{array}{l}\text { Complications: } \\
\text { Related to fits } \\
\text { Related to drugs } \\
\text { Related to hospitalization }\end{array}$ & $\begin{array}{ll}28 & 80.0 \% \\
14 & 40.0 \% \\
4 & 11.4 \%\end{array}$ & $\begin{array}{ll}4 & 57.1 \% \\
1 & 14.3 \% \\
2 & 28.6 \%\end{array}$ & 12.300 & $0.015^{*}$ \\
\hline $\begin{array}{l}\text { Survival: } \\
\text { Death } \\
\text { Survival }\end{array}$ & $\begin{array}{ll}3 & 8.6 \% \\
32 & 91.4 \%\end{array}$ & $\begin{array}{l}228.6 \% \\
571.4 \%\end{array}$ & 2.225 & 0.136 \\
\hline
\end{tabular}

The mean score of EMSE in Group B was significantly higher than Group A, while there was no statistically significant difference between the 2 groups as regard STESS scores (Table 8).

Table (8): STESS and EMSE scores among both studied groups.

\begin{tabular}{lllcc}
\hline & $\begin{array}{c}\text { Group A (n=35) } \\
\text { Non-refractory }\end{array}$ & $\begin{array}{c}\text { Group B (n=7) } \\
\text { Refractory }\end{array}$ & $t$ & $p$ \\
\hline $\begin{array}{lllll}\text { EMSE: } \\
\text { Mean } \pm \text { S.D }\end{array}$ & $\begin{array}{l}74.8 \pm 26.1 \\
\text { Range }\end{array}$ & $\begin{array}{l}128.0 \pm 21.5 \\
1-125\end{array}$ & -5.756 & $0.001^{*}$ \\
STESS: & & & & \\
$\quad$ Mean \pm S.D & $3.2 \pm 1.1$ & $3.6 \pm 1.0$ & -0.974 & 0.355 \\
Range & $1-5$ & $3-5$ & & \\
\hline
\end{tabular}

\section{Discussion}

In the present study regarding socio demographic data both groups didn't show any significant difference although the mean age was higher in the group with non refractory status epilepticus (Group A) and that was in accordance to the study done by Power et al., [6]

Regarding etiology acute symptomatic causes were the most common in both groups, remote symptomatic causes were more common in the non-refractory group while cryptogenic causes were more common in the refractory group with a statistical significance ( $p$-value 0.024 ) this can be explained by the study of Khawaja et al., [7] which showed that New Onset Refractory Status Epilepticus (NORSE) is highly associated with cryptogenic etiology.

Regarding clinical data on admission the mean values of random blood glucose, blood pressure and body temperature were higher in the refractory group but without any statistical significance but Hay et al., [8] reported a significant relation between hyperthermia and refractoriness to treatment this may be attributed to the larger number of patients in their study especially those with CNS infections and unknown etiologies because of to the neurotoxic effect of hyperthermia on brain cells which is almost always associated with poorer outcome.

In the present study EEG abnormalities were significantly more encountered in patients with refractory status epilepticus ( $p$-value 0.015 ), LPDs were the commonest characteristic finding in EEG of studied patients representing $28.6 \%$ of all cases (12 patients) while burst suppression were the least common, we didn't find any significant association between the type of EEG pattern and refractoriness to treatment although Kang et al., [9] reported that periodic epileptic discharges either LPDs or GPDs are associated with RSE and poor outcome.

According to our study both the number of AEDs used and the duration of hospitalization were significantly higher it patients with RSE similar results were reported by Tsai et al., [10] in their study.

Regarding outcome we found that complications due to fits were the most common in both groups but significantly higher in the non refractory group ( $p$-value 0.015 ) while the complications related to hospitalization were more common in the refractory group but without statistical significance. The complications encountered during our study are to somehow similar to those discussed by Hocker et 
al., [11] in their review on the systemic complications of SE in which complications due to seizures itself were the most common, also the survival rate was higher in the non refractory group but with no statistical significance.

In our study the mean score of EMSE in the refractory group was significantly higher than the non refractory group ( $p$-value 0.001 ), while there was no statistically significant difference between the 2 groups as regard STESS scores, there isn't enough studies discussing the relation between STESS and EMSE scores and refractoriness to treatment, but Goyal et al., [12] and Giovannini et al., [13] reported that both EMSE and STESS have an important role in predicting the outcome of SE including morbidity and mortality with EMSE being more sensitive.

\section{Conclusion:}

Most patients presented by SE over the age of 18 has no prior history of epilepsy. CVAs are the leading cause of denovo SE in adults followed by metabolic derangements. Refractory Status Epilepticus (RSE) is associated with prolonged duration of hospitalization and higher rates of complications compared to non-refractory SE. Complications due to seizures were the most common followed by side effects of AEDs while complications of prolonged hospitalization were the least common. EEG monitoring is an important tool both in managing and predicting the outcome of status epilepticus. STESS and EMSE scoring systems are easy to use bed side tools to help in predicting the outcome of SE.

\section{Acknowledgments:}

This research was carried out without funding.

\section{Conflicts of interest:}

No conflicts of interest declared.

\section{Authors' contributions:}

All authors had equal role in design, work, statistical analysis and manuscript writing. All authors have approved the final article work.

\section{References}

1- TRINKA E., et al.: A definition and classification of status epilepticus-Report of the ILAE Task Force on Classification of Status Epilepticus. Epilepsia, 56 (10): p. 1515-23, 2015.

2- SUTTER R., P.W. KAPLAN and S. RUEGG: Outcome predictors for status epilepticus-what really counts. Nat. Rev. Neurol., 9 (9): p. 525-34, 2013.

3- CHO Y.J., et al.: Trafficking patterns of NMDA and GABAA receptors in a $\mathrm{Mg}(2+)$-free cultured hippocampal neuron model of status epilepticus. Epilepsy Res., 136: p. 143-8, 2017.

4- WALKER M.C.: Pathophysiology of status epilepticus. Neuroscience Letters, 2016.

5- HAWKES M.A. and S.E. HOCKER: Systemic Complications Following Status Epilepticus. Current neurology and neuroscience reports, 18 (2): p. 7, 2018.

6- POWER K.N., et al.: Prognostic factors of status epilepticus in adults. Epileptic. Disord., 18 (3): p. 297-304, 2016.

7- KHAWAJA A.M., et al.: New-onset refractory status epilepticus (NORSE)-the potential role for immunotherapy. Epilepsy \& Behavior, 47: p. 17-23, 2015.

8- HAY A., et al.: Characteristics and outcome of patients with the ICU Admission diagnosis of status epilepticus in Australia and New Zealand. J. Crit. Care, 34: p. 14653, 2016.

9- KANG B.S., et al.: Prediction of mortality and functional outcome from status epilepticus and independent external validation of STESS and EMSE scores. Crit. Care, 20: p. $25,2016$.

10- TSAI M.H., et al.: Factors predictive of outcome in patients with de novo status epilepticus. QJM, 102 (1): p. 57-62, 2009.

11-HOCKER S.: Systemic complications of status epilepticusAn update. Epilepsy Behav., 49: p. 83-7, 2015.

12- GOYAL M.K., et al.: Status epilepticus severity score (STESS): A useful tool to predict outcome of status epilepticus. Clinical neurology and neurosurgery, 139: $\mathrm{p}$. 96-9, 2015.

13- GIOVANNINI G., et al.: Mortality, morbidity and refractoriness prediction in status epilepticus: Comparison of STESS and EMSE scores. Seizure, 46: p. 31-7, 2017. 


\section{النوبات الصرعية المستمرة للمرة الآولى فى البالغين:

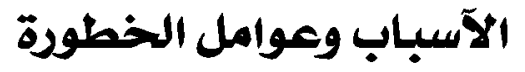

تعتبر النوبات الصرعية المستمرة من الحالات الطارئة المرتبطة بالجهاز العصبى والتى قد تمثل خطورة على حياة المريض، ويتم المبات تعريفها

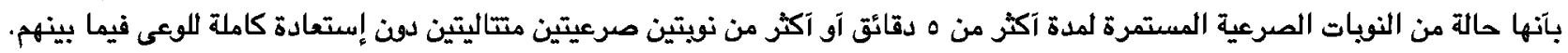

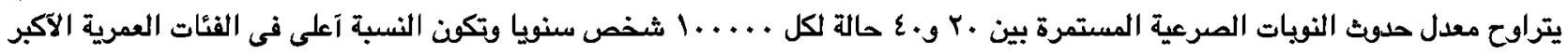

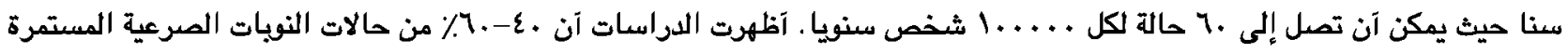

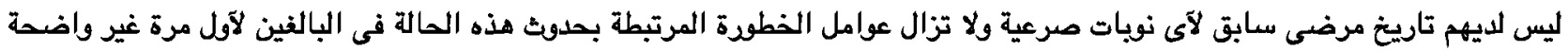

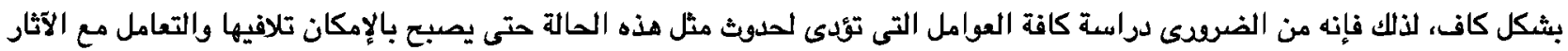
المترتبة بشكل آكثر كثاءة.

الهدف من الدراسة: يهدف هذه البحث إلى دراسة الآسباب وعوامل الخطورة المتعلقة بالنوبات الصرعية المستمرة التى تحدث المرة الآولى

فى البالغين.

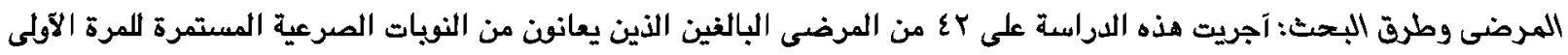

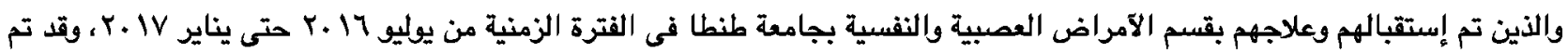

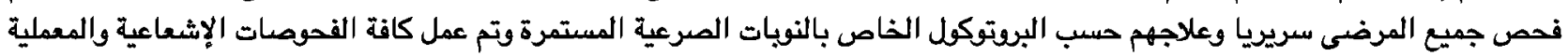

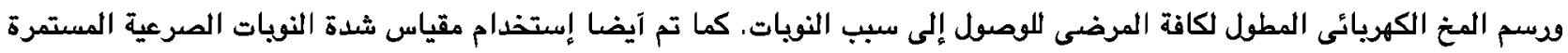

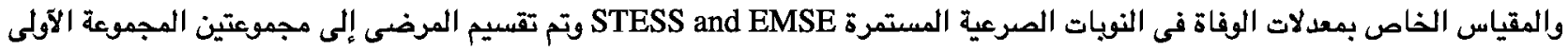

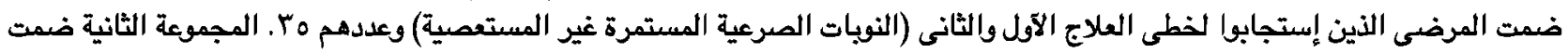

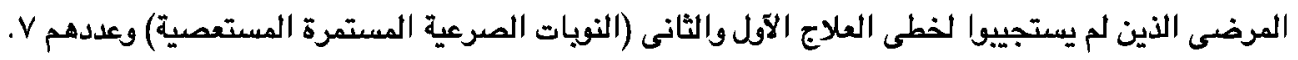

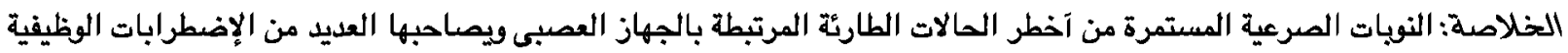

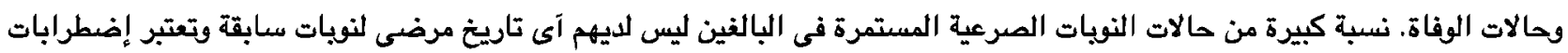

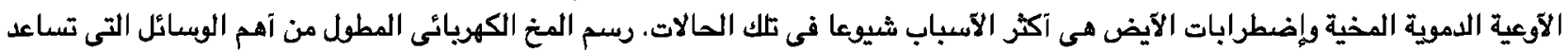

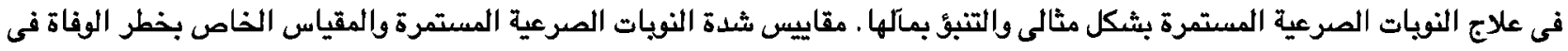

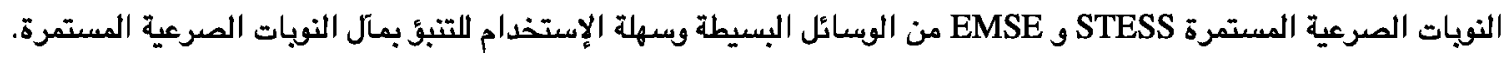

